UCRL-JC-116352

PREPRINT

\title{
Experimental Investigation of Hydrous Pyrolysis of Diesel Fuel and the Effect of Pyrolysis Products on Performance of the Candidate Nuclear Waste Repository at Yucca Mountain, Nevada
}

\author{
Kenneth J. Jackson \\ Susan A. Carroll
}

This paper was prepared for submittal to the

Materials Research Society Annual Meeting

Boston, MA

November 29-December 3, 1993

January 1994

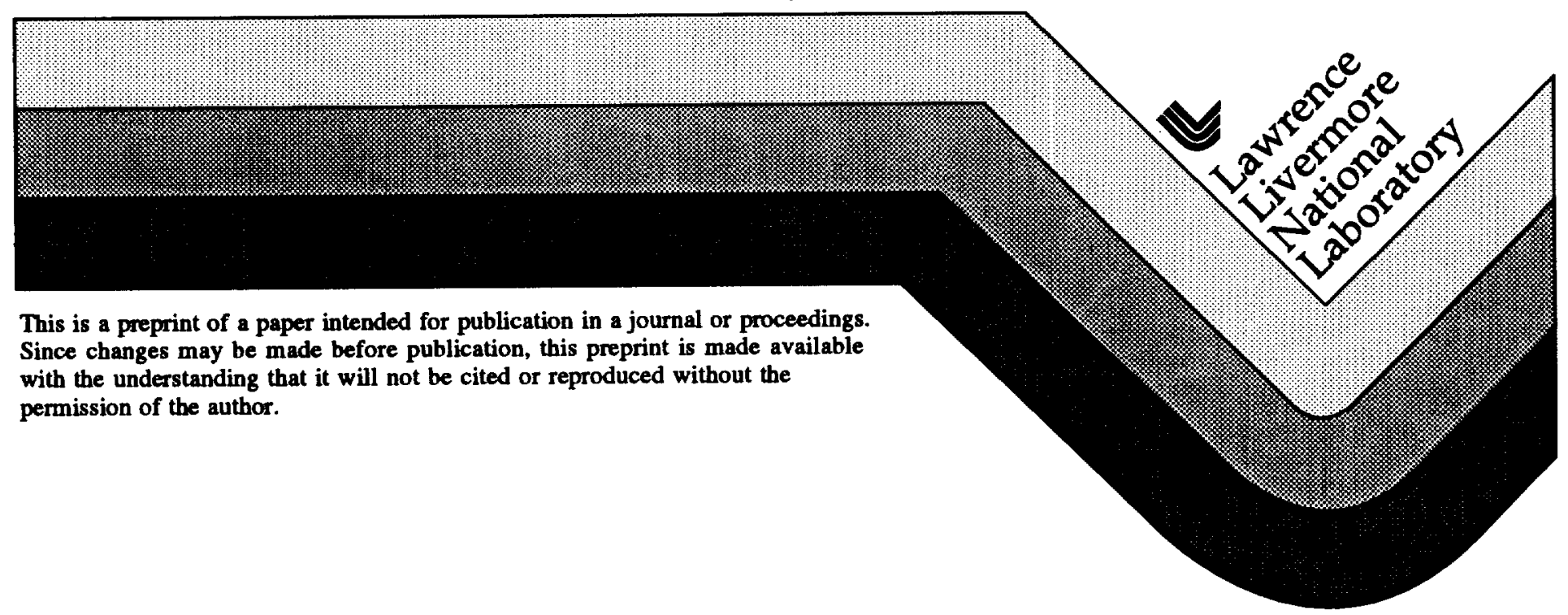




\section{DISCLAIMER}

This document was prepared as an account of work sponsored by an agency of the United States Government. Neither the United States Government nor the University of California nor any of their employees, makes any warranty, express or implied, or assumes any legal liability or responsibility for the accuracy, completeness, or usefulness of any information, apparatus, product, or process disclosed, or represents that its use would not infringe privately owned rights. Reference herein to any specific commercial product, procese, or service by trade name, trademark, manufacturer, or otherwise, does not necessarily constitute or imply its endorsement, recornmendation, or favoring by the United States Government or the University of California. The views and opinions of authors expressed herein do not necessarily state or reflect those of the United States Government or the University of California, and shall not be used for advertising or product endorsement purposes. 
EXPERIMENTAL INVESTIGATION CF HYDROUS PYROLYSIS OF DIESEL FUEL AND THE EFFECT OF PYROLYSIS PRODUCTS ON PERFORMANCE OF THE CANDIDATE NUCLEAR WASTE REPOSITORY AT YUCCA MOUNTAIN,

\section{Kenneth J. Jackson and Susan A. Carroll, Earth Science Division, Lawrence Livermore National Laboratory, Livermore, CA.}

It is thought that a significant amount of diesel fuel and other hydrocarbon-rich phases may remain inside the candidate nuclear waste repository at Yucca Mountain after construction and subsequent emplacement of radioactive waste. Although the proposed repository horizon is above the water table, the remnant hydrocarbon phases may react with hydrothermal solutions generated by high temperature conditions that will prevail for a period of time in the repository. The preliminary experimental results of this study show that diesel fuel hydrous pyrolysis is minimal at $200^{\circ} \mathrm{C}$ and 70 bars. The composition of the diesel fuel remained constant throughout the experiment and the concentration of carboxylic acids in the aqueous phases was only slightly above the detection limit (1-2 ppm) of the analytical technique.

\section{INTRODUCTION}

Under most conditions that prevail at the earth's surface, many complex organic compounds are thermodynamically unstable, and decompose to simpler compounds such as carbon dioxide, methane and water ${ }^{1}$. However, many of these organic compounds persist in nature over extensive time periods, because the kinetic rates of their breakdown reactions are exceedingly slow. It is assumed that some of the organic material introduced to the candidate high-level nuclear waste repository during construction will remain sequestered in the repository after closure and will be available to react at elevated temperatures due to radioactive decay reactions. Although the proposed repository horizon is above the water table, it is easy to envision scenarios in which diesel fuel will be diluted by, mobilized by, and reacted with water produced by dehydration of repository minerals and water mobilized from partially saturated pores during the time elevated temperatures prevail in the repository. Under these conditions of elevated temperature and in the presence of water, many organic compounds are known to break down at greatly accelerated rates. These hydrothermal breakdown reactions of organic compounds (i.e., hydrous pyrolysis) have been observed to generate geochemically reactive species such as carboxylic acids ${ }^{2}$. Additionally, the thermal degradation of organic compounds can impact the oxidation state of the system 3,4 .

The purpose of this study is to experimentally investigate the rate of pyrolysis of diesel fuel and to identify major product phases formed during the hydrothermal destruction of this complex mixture of organic compounds. Diesel fuel was chosen for this study because it is the single largest potential source of organic 
material in the repository (Meike, this volume). A major focus of this study is production of carboxylic acids and other aqueous organic species as the diesel fuel undergoes hydrous pyrolysis, because they could react with the surrounding rocks causing changes in repository porosity, metal canister corrosion rates, or waste form corrosion rates enhancing the mobility of radionuclide species.

\section{EXPERIMENTAL METHODS}

The high temperature pyrolysis experiments were run in Dickson-type, gold bag autoclaves 5 . In this apparatus, the reaction vessel comprises an approximately $250 \mathrm{ml}$ gold bag which is capped with a commercially pure titanium head. The Ti head is fitted with a Ti or Au capillary-lined stainless steel sampling tube that allows the experiment to be sampled periodically during the course of the run at in situ conditions. During the runs, the samples contact only $\mathrm{Au}$ and carefully passivated $\mathrm{Ti}$; minimizing the likelihood of catalysis ${ }^{6}$. The $\mathrm{Au}$ bag assembly is inserted into a stainless steel pressure cell that is filled with deionized water, which serves as the pressure medium. In turn, the pressure cell assembly is fitted into a furnace, as described by 5 .

At the start of the run, the Au bag was partially filled with about $50 \mathrm{~g}$ of diesel fuel and approximately $50 \mathrm{~g}$ of distilled water. The remaining space above the two liquids was filled with high purity $\mathrm{N}_{2}$ gas after emplacing the $\mathrm{Ti}$ head assembly. After the reaction vessel was loaded into the pressure vessel, pressure was gradually increased. This slowly collapsed the Au bag and expelled the $\mathrm{N}_{2}$ gas in the head space leaving only the two-phase mixture of liquid diesel fuel plus liquid water in the reaction vessel. For the work reported in this study, the reaction vessel was heated to $200^{\circ} \mathrm{C}$ and held at a nominal pressure of 70 bars throughout the experiment. This temperature was chosen to accelerate reaction rates so measurable reaction progress could be achieved, and the pressure was selected to keep both liquid phases from boiling.

During the course of the run, the solution was periodically sampled by bleeding off a small amount (usually 1-2 g) of the experimental charge into glass, gas-tight syringes fitted with a Tefion plunger. So that samples could be drawn from both of the liquid phases, the furnace assembly was rotated 180 degrees to access one or the other phase by the sampling tube. The initial samples from both the organic and aqueous portions yielded only liquid, but later samples produced two phases because a gas phase separated from the liquid as the sample cooled. The gas was stripped from the liquid phase using a He gas extraction method6, and the two fractions were analyzed separately. Liquid samples were stored in glass vials, and subsequently diluted in $\mathrm{CS}_{2}$ before analysis by gas chromatography (GC). Liquid sample analysis was done on a Hewlett Packard 5890 Series II GC equipped with a J\&W DB-1 $60 \mathrm{~m}$ capillary column (ID $=0.25$ $\mathrm{mm}$ with a $0.1 \mathrm{~mm}$ coating). A temperature ramp program was run starting at 60 ${ }^{\circ} \mathrm{C}$ for 4 minutes and then increased by $2{ }^{\circ} \mathrm{C}$ per minute to $320^{\circ} \mathrm{C}$ and held at this temperature for a total run time of 160 minutes. The detector was an FID 


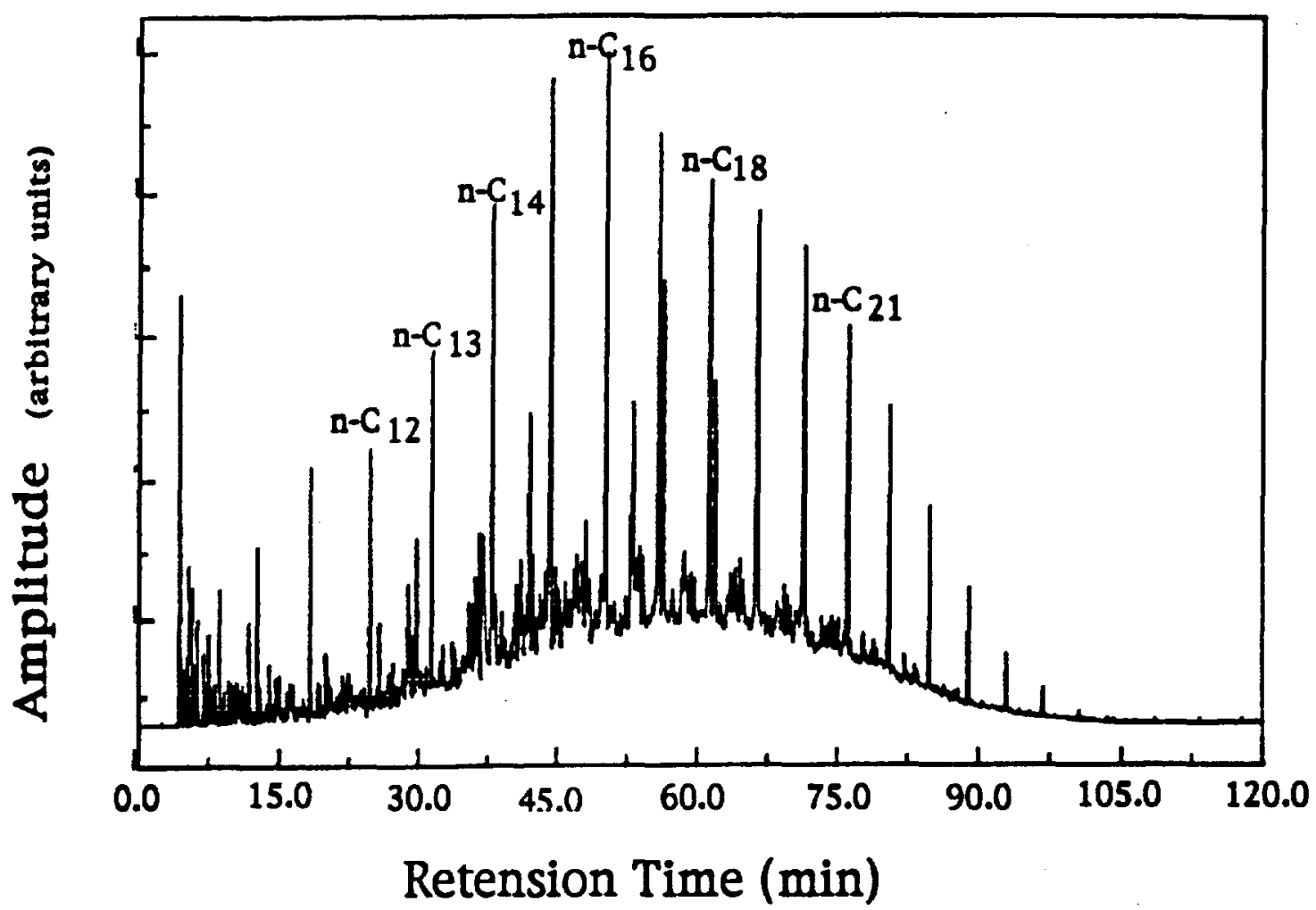

Figure 1. Sample gas chromatograph of a typical diesel fuel sample.

maintained at about $375^{\circ} \mathrm{C}$. The $1 \mathrm{~mL}$ sample was split at a ratio of $\sim 100: 1$ and the injector temperature was held at about $300^{\circ} \mathrm{C}$. Fig. 1 shows a sample analysis of the diesel fuel obtained from the reaction vessel at the beginning of the run.

After the gas extraction step, gas samples were stored in evacuated stainless steal cylinders and subsequently injected directly into a GC sample loop. Gas samples were checked for air contamination using mass spectrographic analyses together with the assumption that any Ar detected in the sample was the result of air introduced during sample handling or during the gas extraction process. Appropriate corrections were made to the measured abundance of gas species based on presumed ideal gas behavior of the components of the gas sample at STP.

\section{RESULTS}

The preliminary experimental results of this study show that diesel fuel hydrous pyrolysis is minimal at $200{ }^{\circ} \mathrm{C}$ and 70 bars. Throughout the duration of the experiment, GC analyses of the diesel fuel fraction remained essentially unchanged. The concentrations of carboxylic acids in the aqueous phases were only slightly above the detection limit (1-2 ppm) of the HPLC technique. The results of this study imply that numerous less abundant compounds are not stable at $200^{\circ} \mathrm{C}$. This is indicated by the observed increase of several organic compounds (including some short chain organic acids) in the aqueous phase 


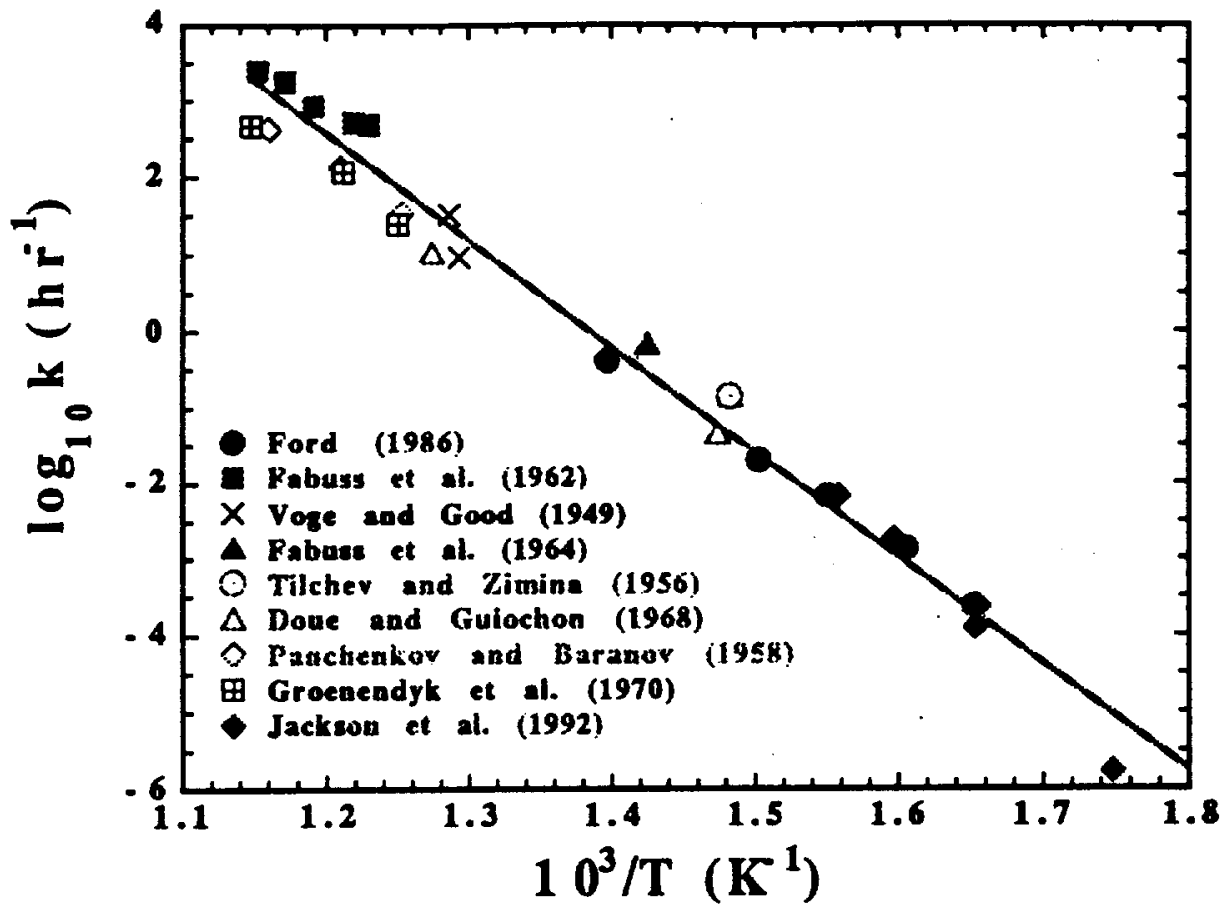

Figure 2. Rate constants $(k)$ for the thermal breakdown of $n$-hexadecane as a function of inverse temperature. References: Ford7, Fabuss et al.8, Voge and Good 9 , Fabuss et al.10, Tilcheev and Zimina11, Doue and Guiochon 12,13, Panchenkov and Baranov 14, Groenendyk et al. ${ }^{15}$, Jackson et al.6.

throughout the course of the experiment. Many of the aqueous organic species have not yet been identified, but their progressive enrichment in the aqueous phase clearly points to the thermal degradation of larger organic compounds in the diesel fuel. Additionally, the observed generation of carbon dioxide (and various gaseous hydrocarbons) in the system together with the increased acidity of the aqueous solution confirm the hypothesis that thermally driven decomposition reactions are occurring in the system .

Although there is little quantitative information about the pyrolysis of complex mixtures like diesel fuel, there is an abundance of experimental information about the thermal stability of some individual hydrocarbon species. A major single component of the diesel fuel used in this work, $n$-hexadecane, is among those extensively investigated compounds (Fig. 1). Therefore, we use this data to estimate the long-term degradation of diesel fuel at likely repository temperatures. The first order rate constants determined for the thermal breakdown of $n-C_{16}$ are plotted as a function of inverse temperature (Fig. 2). As is shown in Fig. 3, degradation rates generated from the data in Fig. 2 can be 


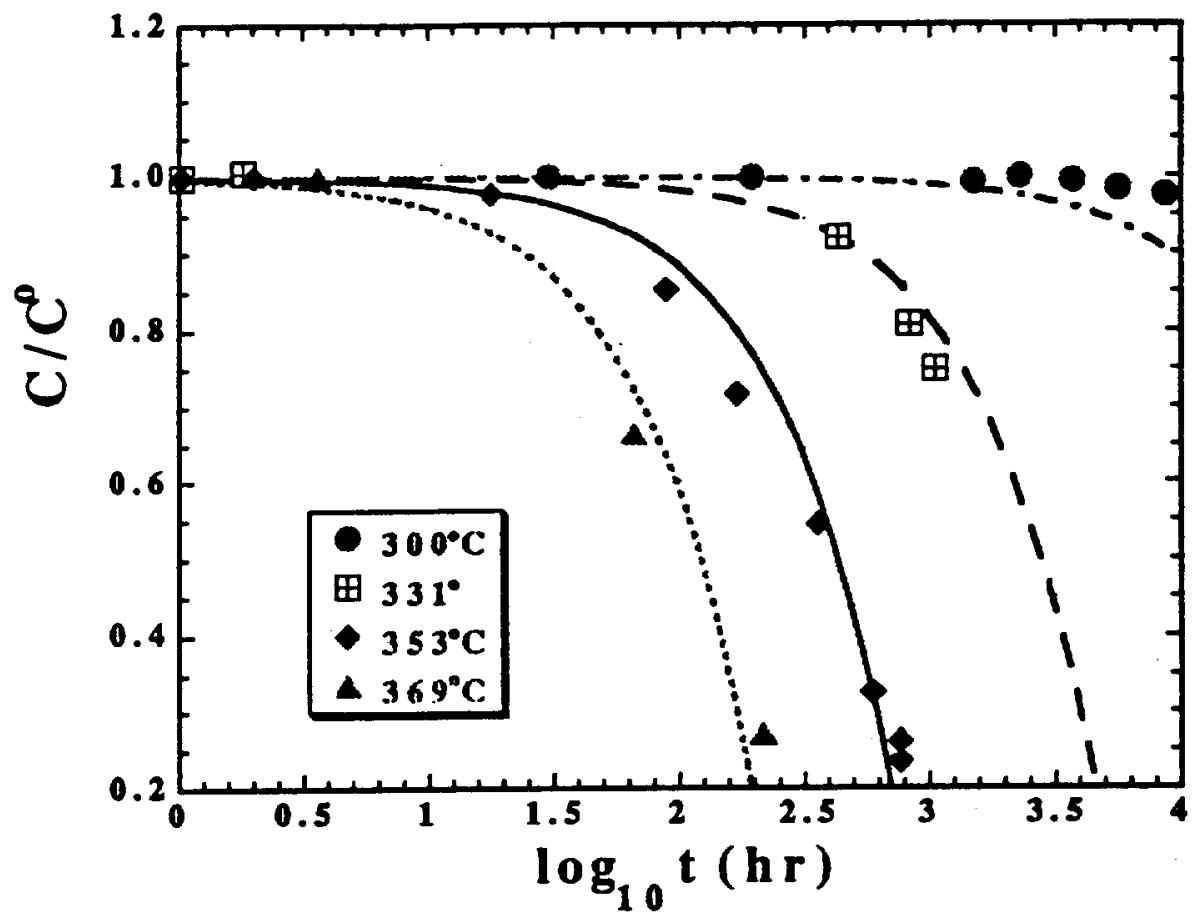

Figure 3. Hexadecane concentration (relative to the original hexadecane abundance: $\mathrm{CO}$ ) decreases as a function of time at elevated temperatures. Data are from Jackson et al. (1992) and curves are generated using extrapolated rate constants generated from the linear fit in Fig. 2

used to describe the rate of disappearance of $n-C_{16}$ as a function of time. If this approach is extrapolated to lower $T$ and assumed to be applicable to other $n$ hydrocarbons (which comprise the bulk of diesel fuel), it can be shown that we should not expect to see measurable decrease in n-hydrocarbon abundance over the duration of our experiment (Fig. 4). In addition, this approach implies that hydrocarbon species may be quite stable for extended periods in the repository system if temperatures remain somewhat lower than $200^{\circ} \mathrm{C}$. Implicit in this approach is the assumption that there is no change in reaction mechanism over the extrapolated temperature range.

\section{FUTURE STUDY}

Based on our initial results, we will design a set of detailed experiments to investigate selected rock-water-organic interactions. Specific reaction products identified in the preliminary phase of the study will be used in these experiments to isolate the most important physical and chemical parameters and reaction mechanisms controlling these interactions. It is important that these experiments be performed with individual organic compounds in order to accurately interpret the data and to enable extrapolation of experimental results 


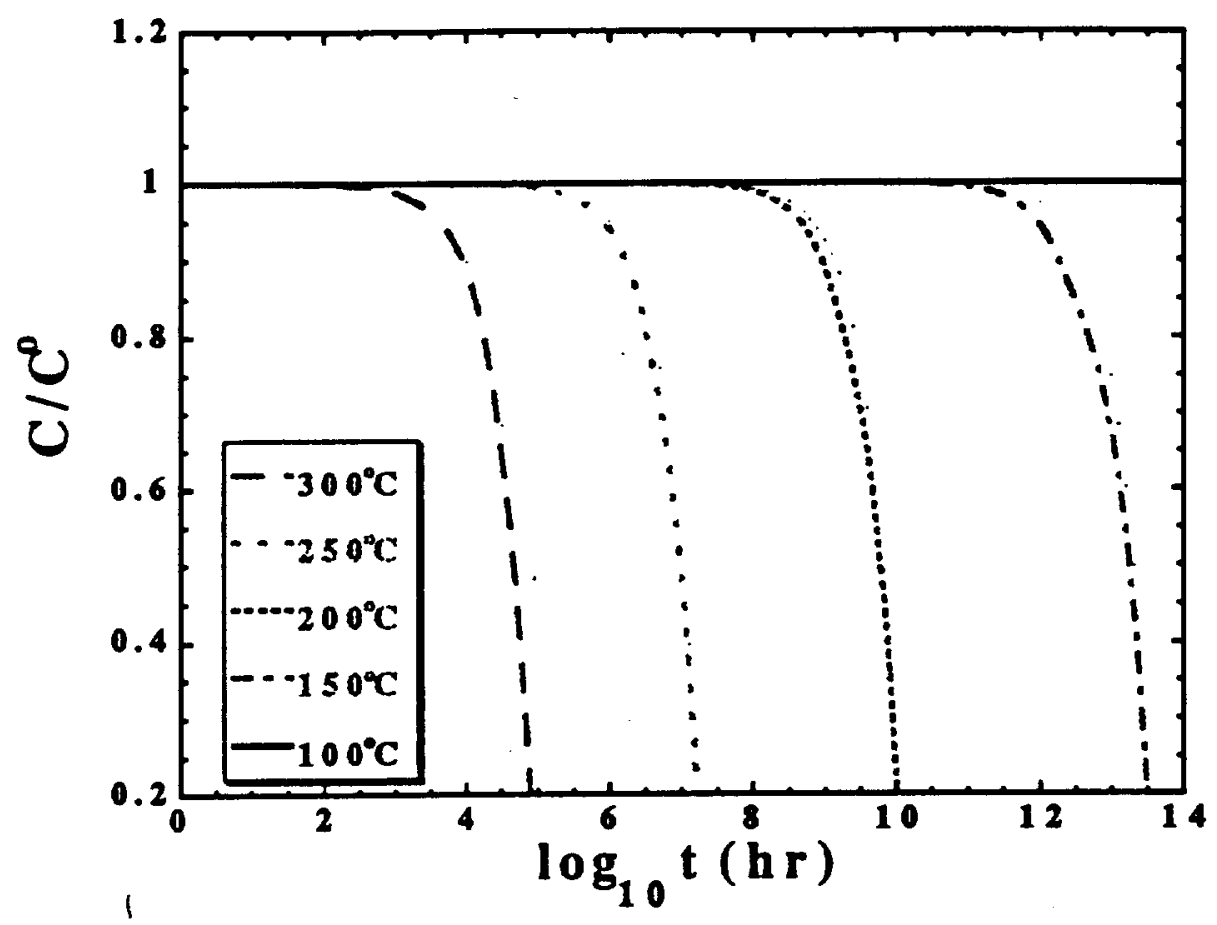

Figure 4. Hexadecane concentrations (relative to $\mathrm{C}^{\circ}$ ) decreases as a function of time at elevated temperatures generated using extrapolated rate constants generated from the linear fit in Fig. 2

to repository conditions. Diesel fuel is a highly complex and variable organic substance. As such, experiments made directly with diesel fuel and the repository rock will be too complicated and ambiguous for performance assessment analysis. It is also desirable to perform these experiments with single mineral phases found in the Topopah Springs tuff to isolate the most important phases involved in the reactions. Minerals, especially clays, are known to catalyze certain pyrolysis reactions. This fact points out the potential for coupled interactions forming a complex feed-back loop, because the minerals accelerate the breakdown of the diesel fuel to other organic compounds that may then dissolve them or cause the precipitation of additional minerals.

This work was performed under the auspices of the U.S. Department of Energy by Lawrence Livermore National Laboratory under Contract W-7405-Eng-48. Prepared by Yucca Mountain Site Characterization Project (YMSCP) participants as part of the Civilian Radioactive Waste Management Program. YMSCP is managed by the Yucca Mountain Site Characterization Project Office of the U.S. Dept. of Energy, Las Vegas, Nevada. 


\section{REFERENCES}

1. Shock, E.L. (1988) Organic acid metastability in sédimentary basins. Geology 16, p. 886-890.

2. Surdam, R. C. and L. J. Crossey (1985) Organic-inorganic reactions during progressive burial: Key to porosity and permeability enhancement and preservation. Phil. Trans. R. Soc. Lond. A 315, 135-156.

3. Rose, N. M. and K. J. Jackson (1991) TERRA Abstr. v. 3, no. 1, European Union of Geosciences, Annual Mtg., VI, Strasbourg, France, p. 468.

4. Jackson, K. J. and N. M. Rose, 1990, Theoretical constraints on organic acid concentrations in oceanic hydrothermal systems. EOS 71, pp. 1570-1571.

5. Seyfried, W. E., D. R. Janecky and M. E. Berndt (1987) Rocking autoclaves for hydrothermal experiments II. The flexible reaction-cell system. In Hydrothermal Experimental Techniques (G. C. Ulmer and H. L. Barnes, eds.) Wiley-Interscience, 216-237.

6. Jackson, K. J., A. K. Burnham, R. L. Braun, and K. G. Knauss (1992) American Chemical Society, Division of Fuel Chemistry, Symposium Series, v. 37, No. 4, pp. 1614-1620.

7. Ford T. J. (1986) Ind. Eng. Chem. Fundam. 25, 240-243.

8. Fabuss, B. M., J. O. Smith, R.I. Lait; A.s. Borsanyi, and C. N. Satterfield (1962), Ind. Eng. Chem. Process Des. Dev. 1, 293.

9. Voge, H. H. and G. M. Good (1949) J. Am. Chem. Soc., 71, 593.

10. Fabuss, B. M., J. O. Smith, and C. N. Satterfield, (1964) Ado. Pet. Chem. Refin. 9, 179.

11. Tilchevv, m. D. and K. I. Zimina (1956) Khim. Tekhnol. Topl. 8, 23.

12. Doue, F. and G. Guiochon (1968) J. Chim. Phys-Chim. Biol. 64, 395.

13. Doue, F. and G. Guiochon (1969) Can. J. Chem. 47, 3477.

14. Groenendyk, H., E. J. Levy, and S. F., Sarner (1970) J. Chromatogr. Sci. 8, 115.

15. Panchenkov, G. M. and B. Y. Baranov (1958) Izo. Vyssh. Uchebn. Zaved., Neft Gaz 1, 703. 


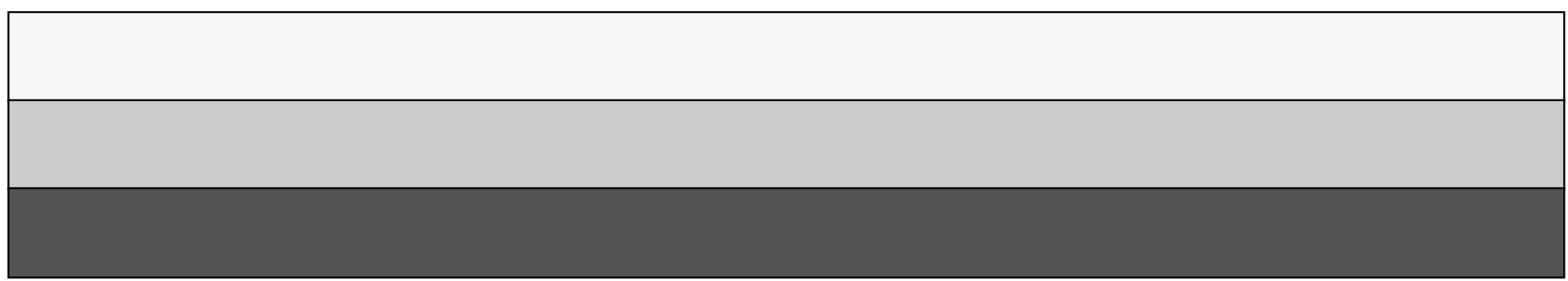

